\title{
Guidelines for Validation of New Names and for Proposals of New Names Which Meet the Criteria for Nomina Revicta
}

\author{
LAWRENCE G. WAYNE \\ Chairman, Judicial Commission
}

The Bacteriological Code (1975 Revision) (1) includes a requirement for validation in the International Journal of Systematic Bacteriology (IJSB) of all new names that have been proposed in journals other than IJSB (see Rule 17). In connection with the establishment of the Approved Lists of Bacterial Names in 1980 (2), the Bacteriological Code provides that names that were omitted from the Approved Lists are available for reuse; in cases in which they are reapplied to the same taxon that originally bore them, they are still to be treated as new names, but their revived status may be indicated by appending the abbreviation "nom. rev." (see Rule 28a). The following editorial policy of IJSB is presented to serve as a guide to authors seeking to validate a new name or combination proposed elsewhere, or to revive a name that was omitted from the Approved Lists, or both.

Validation of names. It is the responsibility of the author(s) of a new name or combination that has been proposed somewhere other than in the IJSB to advise the Editor of IJSB that the proposal has been effectively published (see Rules $25 \mathrm{a}$ and $25 \mathrm{~b}$ for definition of effective publication). At that time the author(s) must provide the editor of IJSB with evidence of effective publication, in the form of either a reprint or a photocopy of those portions of the original publication, that indicates the name of the book or journal and its date and other pertinent citation information and that includes the proposal of the name, the description of the taxon, and the designation of the type. The editor will then publish the name in the next issue of IJSB, thereby validating it as of the date of that issue (see Rule 17). (Names that are proposed originally in the IJSB are automatically validated as of the date of effective publication and thus require no independent validation).

Revival of names (nomina revicta). Names that were omitted from the Approved Lists thereby lost nomenclatural standing. It is recognized that some names that were omitted may indeed represent taxa that deserve revival, and the Bacteriological Code (1) provides for such instances (see Rule 28a). This guideline is presented to assist authors in preparing proposals for revival of names. (Provisional Rules B 14 provide some guidance for citation of reused names, but they have not yet been formally incorporated into the Code). (i) Proposals for reuse of names that were omitted from the Approved Lists should be submitted for publication by individuals, not by committees, although an appropriate committee may elect to endorse a proposal.

(ii) The name to be reused must be proposed as a new name ascribed to the author(s) making the current proposal, but the revived status may be indicated by appending the abbreviation "nom. rev." (Rule 28a) and citing the earlier author(s) in the form suggested in Provisional Rule B3.

(iii) The proposal must contain a brief statement (or list) of those features that led the author(s) to conclude that the proposed taxon is sufficiently different from other, recognized taxa to justify its revival. The data included in that statement may be taken from the earlier description, and newer data may be added when appropriate.

(iv) The proposal must include designation of the type. It is desirable that a description of the type or a statement of the degree of concordance between the description of the type and of the taxon as a whole be included, as well as the collection number of that strain as listed by a major national collection.

(v) Publication of the proposal is not restricted to IJSB, but if it appears in another journal, a request must be sent to the editor of the IJSB to effect validation as for any other new name. This can only be done after effective publication of the proposal in the other journal.

(vi) Rule $28 \mathrm{a}$ also permits reuse of a name that was omitted from the Approved Lists for a taxon other than one to which it was originally applied. That provision was necessary to permit the new priority date (1 January 1980) for all names to serve its intended function, i.e., to eliminate the need for searching through old literature for obscure names before naming a new taxon. Nevertheless, an author who is already aware of a prior use of a name would be well advised to avoid reapplying it to a new and different taxon (see also Provisional Rule B4).

\section{L'TERATURE CITED}

1. Lapage, S. P., P. H. A. Sneath, E. F. Lessel, V. B. D. Skerman, H. P. R. Seeliger, and W. A. Clark (ed). 1975. International code of nomenclature of bacteria. American Society for Microbiology, Washington, D.C.

2. Skerman, V. B. D., V. McGowan, and P. H. A. Sneath (ed). 1980. Approved lists of bacterial names. Int. J. Syst. Bacteriol. 30:225-420. 